\title{
Article \\ Surface Enhanced Raman Spectroscopy With Electrodeposited Copper Ultramicro-Wires With/Without Silver Nanostars Decoration
}

\author{
Margherita Longoni ${ }^{1,2}$ (D, Maria Sole Zalaffi ${ }^{1} \mathbb{D}$, Lavinia de Ferri ${ }^{3,4}$, Angela Maria Stortini ${ }^{1}$, Giulio Pojana ${ }^{3} \mathbb{D}$ \\ and Paolo Ugo ${ }^{1, * \mathbb{D}}$
}

Citation: Longoni, M.; Zalaffi, M.S.; de Ferri, L.; Stortini, A.M.; Pojana, G.; Ugo, P. Surface Enhanced Raman Spectroscopy With Electrodeposited Copper Ultramicro-Wires With/Without Silver Nanostars Decoration. Nanomaterials 2021, 11, 518. https://doi.org/10.3390/ nano11020518

Academic Editor: Werner Blau

Received: 21 January 2021

Accepted: 16 February 2021

Published: 18 February 2021

Publisher's Note: MDPI stays neutral with regard to jurisdictional claims in published maps and institutional affiliations.

Copyright: (C) 2021 by the authors Licensee MDPI, Basel, Switzerland. This article is an open access article distributed under the terms and conditions of the Creative Commons Attribution (CC BY) license (https:/ / creativecommons.org/licenses/by/ $4.0 /)$.
1 Department of Molecular Sciences and Nanosystems, University Ca' Foscari of Venice, via Torino 155, 30172 Venice, Italy; margherita.longoni@unimi.it (M.L.); mariasole.zalaffi@unive.it (M.S.Z.); stortini@unive.it (A.M.S.)

2 Department of Chemistry, University of Milan, via C. Golgi 19, 20133 Milano, Italy

3 Department of Philosophy and Cultural Heritage, University Ca' Foscari of Venice, Dorsoduro 3484/d, 30123 Venice, Italy; lavinia.deferri@unive.it (L.d.F.); jp@unive.it (G.P.)

4 Department of Collection Management-Museum of Cultural History, University of Oslo, Kabelgata 34, 0580 Oslo, Norway

* Correspondence: ugo@unive.it

\begin{abstract}
The electrochemical preparation of arrays of copper ultramicrowires (CuUWs) by using porous membranes as templates is critically revisited, with the goal of obtaining cheap but efficient substrates for surface enhanced Raman spectroscopy (SERS). The role of the materials used for the electrodeposition is examined, comparing membranes of anodized aluminum oxide (AAO) vs. track-etched polycarbonate (PC) as well as copper vs. glassy carbon (GC) as electrode material. A voltammetric study performed on bare electrodes and potentiostatic tests on membrane coated electrodes allowed the optimization of the deposition parameters. The final arrays of CuUWs were obtained by chemical etching of the template, with $\mathrm{NaOH}$ for $\mathrm{AAO}$ and $\mathrm{CH}_{2} \mathrm{Cl}_{2}$ for $\mathrm{PC}$. After total etching of the template, SERS spectra were recorded on CuUWs using benzenethiol as SERS probe with known spectral features. The CuUW substrates displayed good SERS properties, providing enhancement factor in the $10^{3}-10^{4}$ range. Finally, it was demonstrated that higher Raman enhancement can be achieved when CuUWs are decorated with silver nanostars, supporting the formation of SERS active hot-spots at the bimetallic interface.
\end{abstract}

Keywords: copper; ultramicrowire; silver nanostars; template; electrochemical deposition; anodized aluminum oxide; track-etched polycarbonate; SERS; benzenethiol

\section{Introduction}

Recent years have seen increased interest in the development of miniaturized analytical sensors based on arrays of ultramicro- and nanowires [1-3] which, thanks to their microscopic structure, allow to achieve significantly improved analytical performances, especially as far as sensitivity and possibility of miniaturization are concerned [4-6]. Here we will use the term nanowire (NW) and ultramicrowire (UW) for a cylindrical conductor with diameter $\leq 100 \mathrm{~nm}$ and in the 100-500 $\mathrm{nm}$ range, respectively. It is worth reminding that a micro- or nanowire is defined as any cylindrical conductor with aspect ratio (i.e., length/diameter) $\geq 20$ [7]. Numerous examples of novel sensors based on arrays of NWs or UWs, which exploit electrochemical or optical transduction, have been presented and reviewed [1-3,8-10].

One of the most widely used methods for preparing arrays of microscopic wires is the membrane templated deposition [11-14]. Typically, anodized aluminum oxide (AAO) or track-etched polycarbonate (PC) membranes are used to this aim [12-20]. From a morphological viewpoint, both AAO and PC membrane exhibit monodisperse pores, with 
a diameter determined by the anodization potential for the former and by the etching time for the latter [14]. AAO membranes are characterized by very dense and orderly pores, arranged in a hexagonal pattern, but are rigid and fragile. Track-etched PC membranes present instead sparse and randomly arranged pores, but with the advantage of a greater flexibility.

The growth of the nanowires in the template can be obtained by chemical or electrochemical methods [12-16]. In particular, the electrochemical deposition of metal nanowires requires that one membrane side is in direct electronic contact with a conductive surface (electrode). Interestingly, the electrochemical deposition starts from the interface between the electrode surface and the electrolyte at the bottom of the pore, to develop progressively along the main axes, so that, by controlling the deposition time it is possible to control the wire length [21-24]. In order to maximize the aspect ratio of the templated wires, the electrochemical deposition should be stopped when the filling of the pores is almost complete, that is a few seconds before the metal deposit begins to develop on the external surface of the membrane. The obtained nanowires can be separated by the template by physical [25,26] or chemical etching [27-29]. Recently, arrays of copper wires, both copper nanowires (CuNWs) and ultramicro-wires (CuUWs), gained the interest of researchers thanks to their catalytic, electronic, and photo(electro)chemical properties, together with a significantly lower cost than noble metal equivalents [30-32].

Indeed, several reports have dealt with the preparation and electrochemical sensing application of CuNWs arrays by template synthesis both in AAO [15,30,31] and tracketched PC membranes [22,23,33,34]. In the first part of the present work, we have revisited and compared the role of some parameters that can influence the electrochemical deposition of copper wires such as: (i) the nature of the template (AAO vs. PC); (ii) the material of the substrate electrode (copper vs. glassy carbon); and (iii) the concentration of $\mathrm{Cu}^{2+}$ ions in the electrolyte. In particular, we focused on arrays of $\mathrm{CuUWs}$ whose preparation can be easily performed in any chemical laboratory.

The obtained CuUWs have been examined with respect to their application as substrates for SurfaceEnhanced Raman Spectroscopy (SERS). SERS is a spectroscopic analytical technique, which takes advantage of the dramatic enhancement of the Raman signal produced by the interaction of the molecule under study with nanostructured metal surfaces [35-38]. This allows the sensitive detection of the analyte even in complex samples such as living cells $[39,40]$. Recent researches have demonstrated that membrane templated nanowires are highly effective in producing SERS effects [41-45]. To date, only few studies have examined the generation of SERS effects with copper wires of microscopic dimension [46-48], and no reports have examined the possibility to exploit membrane-templated CuNWs or CuUWs to this aim. Recently it was proven both experimentally and theoretically that decorating metal nanowires (in particular AuNWs) with silver anisotropic nanostructures, such as silver nanostars (AgNSs), further increases the SERS effect already produced by the nanowires [45]. Theoretical calculations demonstrated that this is related to the generation of SERS active hot spots at the interface between nanostars and nanowires. All these observations prompted us to study the possible extension of similar SERS effects to arrays of CuUW arrays, both before and after decoration with AgNSs.

\section{Materials and Methods}

\subsection{Chemicals and Materials}

All chemicals were of analytical grade and used without further purification. Solutions were prepared using double distilled water $\left(18.2 \mathrm{M} \Omega \mathrm{cm}^{-1}\right)$.

Nafion ${ }^{\circledR} 117,5 \% w / v$ hydroalcolic solution (Sigma-Aldrich) was diluted to $1 \%$ with methanol before use.

The $\mathrm{Cu}$ deposition was typically performed at room temperature in electrolyte solutions of $\mathrm{CuSO}_{4}$ in $10^{-2} \mathrm{M} \mathrm{H}_{2} \mathrm{SO}_{4}$ and $2 \mathrm{M} \mathrm{Na}_{2} \mathrm{SO}_{4}$ [23].

The membranes used as templates were: (i) track-etched polycarbonate SPI-Pore membranes by SPI-Supplies (West Chester, PA, USA): pore diameter $400 \mathrm{~nm}$, thickness 
$10 \mu \mathrm{m}$, pore density $1 \times 10^{8}$ pores $\mathrm{cm}^{-2}$, treated by the producer with polyvinylpyrrolidone as wetting agent; (ii) anodized aluminum oxide AAO wafer membranes by InRedox (Longmont, CO, USA): pore diameter $200 \pm 22 \mathrm{~nm}$, thickness $50 \pm 10 \mu \mathrm{m}$, pore density $5.7 \times 10^{8}$ pores $\mathrm{cm}^{-2}$.

Figure 1 shows the SEM images of the surface of the two AAO and PC membranes applied here.

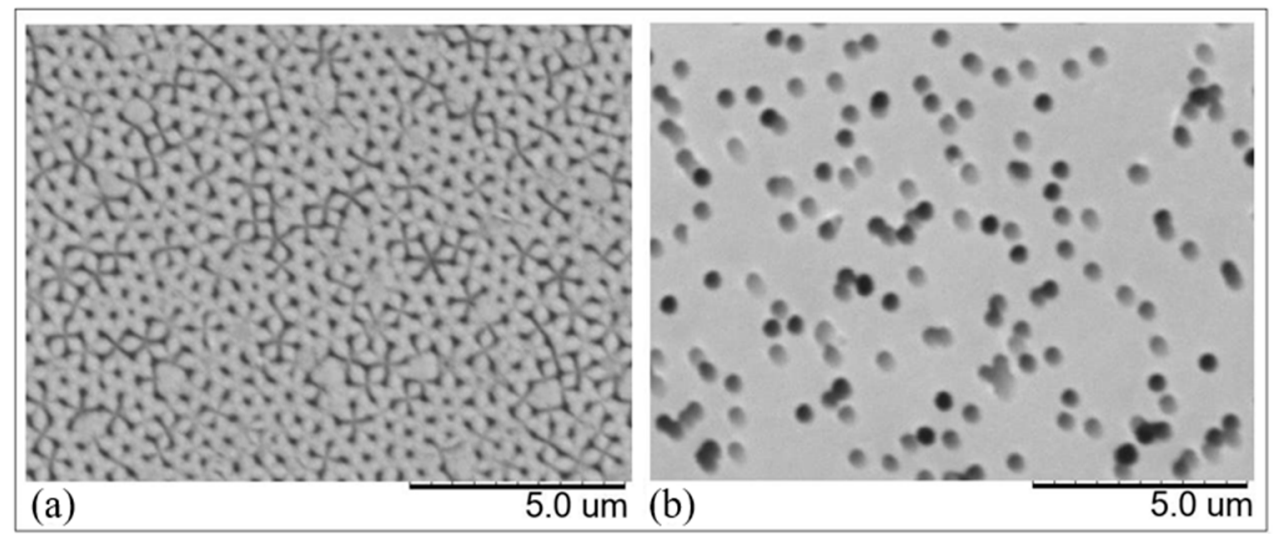

Figure 1. Scanning electron microscopy images of the surface of the membranes here used as templates: (a) anodized aluminum oxide; (b) track-etched polycarbonate.

\subsection{Electrochemical Methods}

Electrochemical measurements were performed with a CHI1000 workstation $(\mathrm{CH}$ Instruments, Austin, TX, USA). Cyclic voltammetry (CV) was performed at room temperature using a three-electrode cell set up. The working electrode was a glassy carbon disk (GC) or a Cu disk electrode (diameter of 5 and $3 \mathrm{~mm}$, respectively), mirror-polished with graded alumina $(1,3$ and $0.5 \mu \mathrm{m})$, ultrasonicated and carefully rinsed with water before use. A Pt coil was used as a counter electrode. In order to prevent the presence of chloride ions, which can alter the reduction mechanism of copper [49], a copper plate was used as a pseudo-reference electrode, hereafter indicated as $\mathrm{Cu}$ (pseudo ref).

All membrane templated electrochemical depositions were performed at room temperature operating at a constant potential, using a conventional single-compartment cell equipped with a copper plate counter electrode and a $\mathrm{Cu}$ (pseudo ref). The working electrodes were GC or $\mathrm{Cu}$ disk electrodes, described above, coated with the AAO or PC templating membrane by using the procedure schematized in Figure 2 and described in Sections 2.3 and 2.4 .

\subsection{CuUWs by Polycarbonate Membrane}

Copper ultramicrowires deposition was carried out on PC membranes with $400 \mathrm{~nm}$ pore diameter. To improve electrical contact with the supporting electrode, one side of the template membrane was sputtered with a thin layer of gold (average thickness $75 \mathrm{~nm}$ ). In order to improve the adhesion between PC and the metal substrate, $10 \mu \mathrm{L}$ of $1 \% w / v$ Nafion solution were used as ionically conductive glue [32]. The electrochemical deposition was carried out in $0.30 \mathrm{M} \mathrm{CuSO}_{4}, 2 \mathrm{M} \mathrm{Na}_{2} \mathrm{SO}_{4}, 10^{-2} \mathrm{M} \mathrm{H}_{2} \mathrm{SO}_{4}$ electrolyte solution. After the deposition, the $\mathrm{PC}$ template was removed by chemical etching with pure dichloromethane for one minute. 


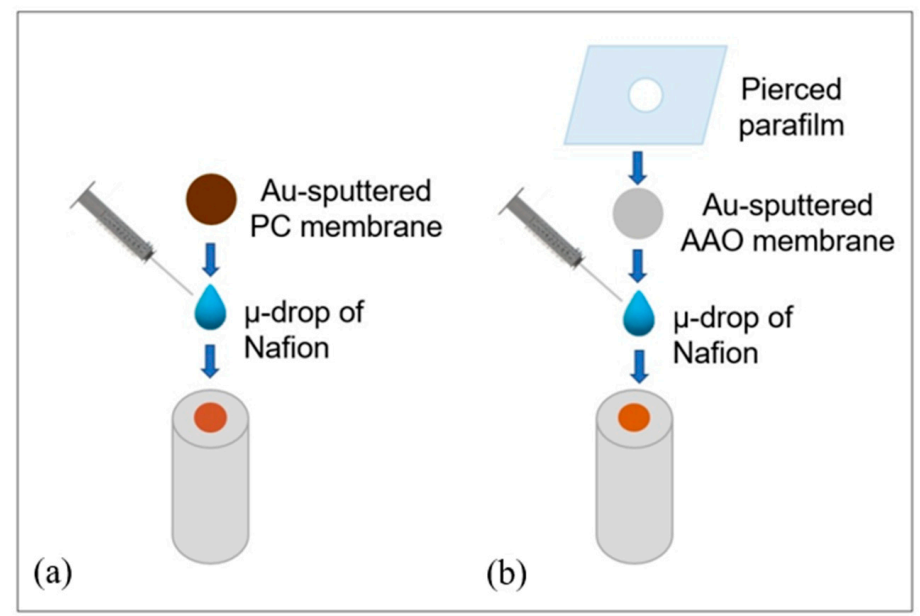

Figure 2. Scheme illustrating the method used to fix the template membrane on the working electrode for the case of: (a) track-etched polycarbonate; (b) anodized aluminum oxide.

\subsection{CuUWs by Alumina Membrane}

The CuUWs deposition was carried out on AAO wafer membranes with pores of $200 \mathrm{~nm}$ diameter. As for the PC membrane, pre-sputtering with a thin gold layer was performed. In order to improve adhesion, in addition to using the microvolume of Nafion solution, the template was fixed on its outer border with Parafilm (Figure 2b). After the deposition in $0.30 \mathrm{M} \mathrm{CuSO}_{4}, 2 \mathrm{M} \mathrm{Na}_{2} \mathrm{SO}_{4}, 10^{-2} \mathrm{M} \mathrm{H}_{2} \mathrm{SO}_{4}$ solution, the AAO template was removed by chemical etching in $2 \mathrm{M} \mathrm{NaOH}$ for $5 \mathrm{~min}$.

\subsection{Preparation of Silver Nanostars}

Colloidal dispersions of silver nanostars (AgNSs) were prepared using the one-pot method previously described $[45,50,51]$ where hydroxylamine, citrate, and $\mathrm{NaOH}$ were used as reducing and shape directioning agents.

Briefly, $0.5 \mathrm{~mL}$ of $0.05 \mathrm{M} \mathrm{NaOH}$ and $0.5 \mathrm{~mL}$ of hydroxylamine $(0.18 \% w / v)$ solutions were mixed under stirring for one minute. Then, $9 \mathrm{~mL}$ of a $10^{-3} \mathrm{M} \mathrm{AgNO}_{3}$ solution were added with stirring for further $5 \mathrm{~min}$. Afterwards, $100 \mu \mathrm{L}$ of a $90.045 \mathrm{M}$ citrate solution were dropped in the flask, continuing stirring for approximately $15 \mathrm{~min}$, i.e., until it developed a dark green color. Then the flask was stored in the dark at room temperature to complete the growth of the star-shaped NPs, which took approximately $48 \mathrm{~h}$. The suspension was concentrated before use as described in ref. [45]. Figure 3 shows the TEM image of the here-obtained nanostars.



Figure 3. Transmission electron microscopy image of the silver nanostars. 


\subsection{Samples for SERS Analysis}

For SERS measurements, benzenethiol (BT) was used as Raman probe with known spectral features. Before SERS analyses, the structures under study were incubated overnight in a $10^{-3} \mathrm{M}$ BT solution in ethanol, followed by gentle washing with pure ethanol.

The structures used as SERS substrates were: (i) flat copper plate, used as reference material; (ii) CuUWs on GC; (iii) CuUWs decorated with AgNSs (AgNS@CuUW). The preparation of the final samples for SERS analyses are detailed below:

(i) Metallic copper plate (approximately, $1 \mathrm{~cm} \times 0.8 \mathrm{~cm}$ ): the metallic surface was mirror polished with fine grain emery paper and graded alumina powder $(1,3$ and $0.5 \mu \mathrm{m}$ granulometry), carefully rinsed with water just before use.

(ii) CuUWs: the arrays were grown on GC using PC as the templating membrane (see above).

(iii) AgNS@CuUW: when required, the above CuUWs arrays were decorated with AgNSs by applying the procedure previously reported for similar nanostructures, but supported on gold nanowires. Briefly, the procedure included: (i) overnight immersion of the CuUWs in $10^{-2} \mathrm{M}$ cysteamine solution in water; (ii) overnight immersion in a colloidal dispersion of silver nanostars (AgNSs). Careful washing with deionized water was performed between each step. Cysteamine was used to bridge the nanostars onto the ultramicrowires [45].

\subsection{SERS Measurements}

SERS analyses were performed using a B\&WTek (Newark, DE, USA) i-Raman 785S spectrometer equipped with a diode laser operating at $785 \mathrm{~nm}$. The maximum power was $300 \mathrm{~mW}$ and the nominal spectral resolution $4.5 \mathrm{~cm}^{-1}$. The spectrometer is coupled with BAC151B (B\&W Tek, Inc.) microscope through optical fibers (1.5m length); a $20 \times$ objective was used to collect spectra in the $175-3000 \mathrm{~cm}^{-1}$ spectral range. with a typical integration time of $20 \mathrm{~s}$. Spectra were acquired using the BWspec4 software; the post-processing of the data was performed with the OriginLab software.

\subsection{Electron Microscopy}

Scanning Electron Microscopy (SEM) and energy dispersive spectroscopy (EDS) analysis were performed using a TM3000 Hitachi tabletop scanning electron microscope, coupled with an X-ray microanalysis system (SwiftED3000); conditions for recording the EDS spectra were: acquisition time $30.0 \mathrm{~s}$; process time $5 \mathrm{~s}$; accelerating voltage $15 \mathrm{kV}$.

Transmission electron microscopy (TEM) was performed using a JEOL $3010(0.17 \mathrm{~nm}$ point-to-point resolution at Scherzer defocus), operating at $300 \mathrm{kV}$, equipped with a Gatan slow-scan CCD camera (model 794).

\section{Results and Discussion}

\subsection{Voltammetric Study of $\mathrm{Cu}^{2+}$ Reduction}

In order to find the best conditions for the electrochemical deposition of copper, preliminary analyses were performed by cyclic voltammetry in $\mathrm{CuSO}_{4}$ solutions, with $2 \mathrm{M} \mathrm{Na}_{2} \mathrm{SO}_{4}, 10^{-2} \mathrm{M} \mathrm{H}_{2} \mathrm{SO}_{4}$ as the supporting electrolyte [23]. Preliminary tests indicated that the $\mathrm{CV}$ patterns remained substantially unchanged varying both $\mathrm{Na}_{2} \mathrm{SO}_{4}$ and $\mathrm{H}_{2} \mathrm{SO}_{4}$ concentrations in the $0.5-2 \mathrm{M}$ and $5 \times 10^{-3}-1 \times 10^{-2} \mathrm{M}$ range, respectively.

Figure 4 compares the cyclic voltammograms, recorded at $40 \mathrm{mV} / \mathrm{s}$ using a copper working electrode (A) and a GC-disk working electrode (B). On the copper working electrode, a cathodic peak was detected at around $-0.230 \mathrm{~V}$ vs. $\mathrm{Cu}$ (pseudo ref) in the CV cathodic branch, while the anodic branch was characterized by an almost linear growth of the current at potentials higher than $+0.02 \mathrm{~V}$. The reduction peak was due to the twoelectron reduction of $\mathrm{Cu}^{2+}$ ions, which diffused from the bulk solution to the surface of the electrode. The anodic current increased without creating a peak because it corresponded to 
the oxidation of both the metallic copper deposited during the cathodic branch of the CV and the metallic copper that constitutes the electrode itself.

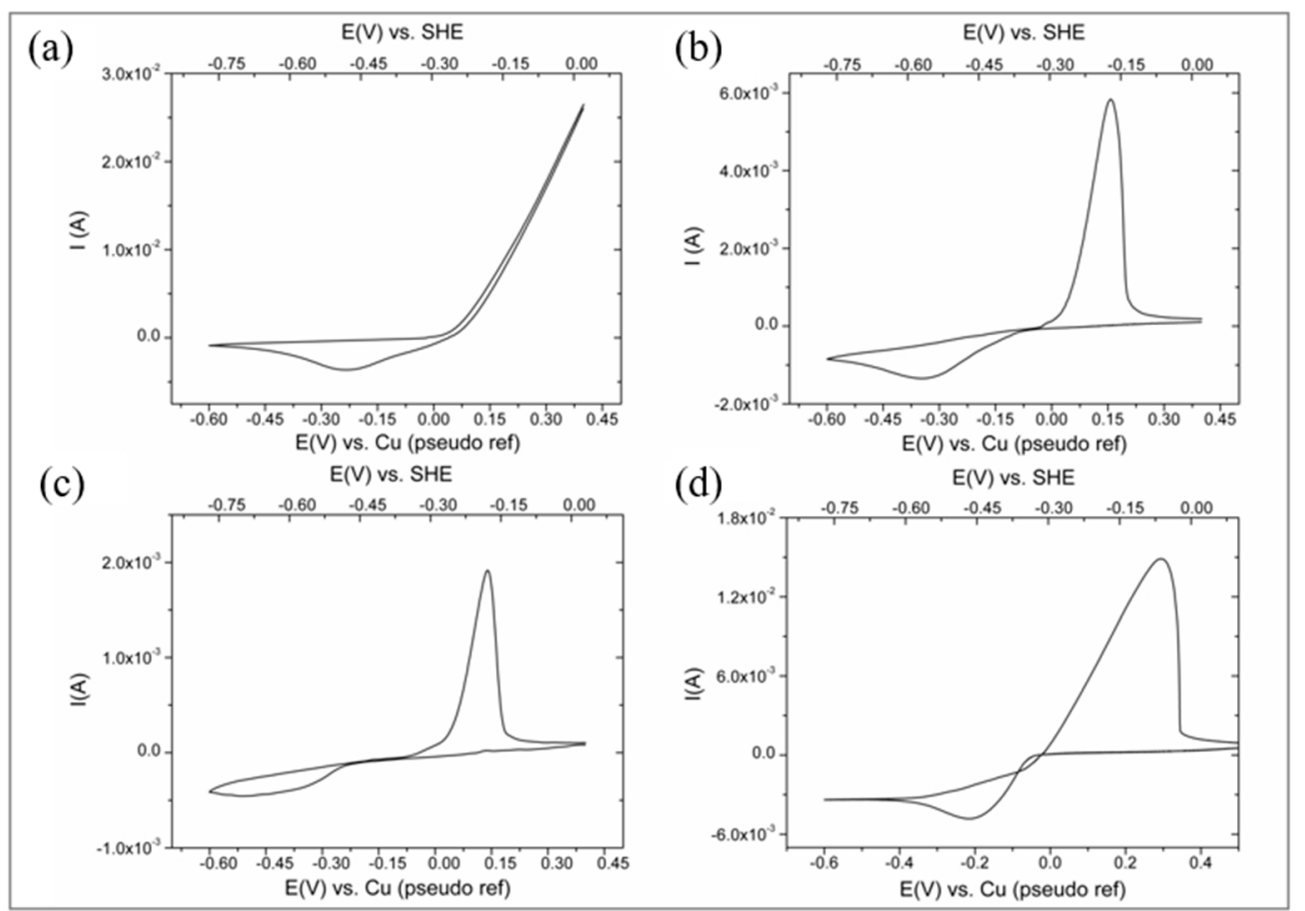

Figure 4. Cyclic voltammograms recorded at $40 \mathrm{mV} / \mathrm{s}$ in $0.01 \mathrm{M} \mathrm{H}_{2} \mathrm{SO}_{4}, 2 \mathrm{M} \mathrm{Na}_{2} \mathrm{SO}_{4}$ solution: (a) with $\mathrm{Cu}$ working electrode in the presence of $0.05 \mathrm{M} \mathrm{CuSO}_{4} ;(\mathbf{b}-\mathbf{d})$ with GC working electrode in the presence of $0.05 \mathrm{M}, 0.01 \mathrm{M}$ and $0.3 \mathrm{M}$ $\mathrm{CuSO}_{4}$, respectively.

In the case of glassy carbon electrode (Figure $4 \mathrm{~b}$ ), the $\mathrm{CV}$ cathodic branch presented a peak at $-0.35 \mathrm{~V}$ vs. $\mathrm{Cu}$ (pseudo ref), while the anodic one showed a symmetric peak at about $+0.140 \mathrm{~V}$ vs. $\mathrm{Cu}$ (pseudo ref), showing the shape typical for a cathodic deposition and anodic stripping related to the two electron process:

$$
\mathrm{Cu}^{2+}+2 \mathrm{e}^{-} \leftrightarrows \mathrm{Cu}^{0}
$$

The reduction peak of $\mathrm{Cu}^{2+}$ to $\mathrm{Cu}^{0}$ was shifted to slightly more negative potentials on GC with respect to copper. This is because the deposition of copper on GC is more energy demanding than the deposition of copper on copper, the first process being affected by a higher overpotential because of the energy required to form the first metallic nuclei on a foreign substrate (i.e., glassy carbon) [52,53].

Focusing on the deposition of $\mathrm{Cu}$ on GC, Figure 4c,d shows the $\mathrm{CV}$ recorded at different $\mathrm{CuSO}_{4}$ concentrations, namely $0.01 \mathrm{M}$ and $0.3 \mathrm{M}$.

It is worth reminding that the potential of the $\mathrm{Cu}$ (pseudo ref) depends on $\mathrm{CuSO}_{4}$ concentration. This is not a problem when operating always at the same $\mathrm{Cu}^{2+}$ concentration, but this dependence must be taken into account when operating with different $\mathrm{Cu}^{2+}$ concentrations. The $\mathrm{Cu}$ (pseudo ref) electrode behaves indeed as a 1st kind electrode whose potential [53] is given by:

$$
\mathrm{E}_{\mathrm{Cu} \text { (pseudo ref) }}=\mathrm{E}+0.059 / 2 \log \left[\mathrm{Cu}^{2+}\right]=0.340+0.059 / 2 \log \left[\mathrm{Cu}^{2+}\right](\mathrm{V} \text { vs. SHE })
$$

where SHE is the standard hydrogen electrode.

It can be easily calculated that, in $1 \times 10^{-2}, 1 \times 10^{-2}$ and $3 \times 10^{-1} \mathrm{M} \mathrm{CuSO}_{4}$ solutions the potential of the Cu-pseudo is $0.280,0.300,0.320 \mathrm{~V}$ vs. SHE, respectively.

Therefore, in order to perform a correct evaluation, in Figure 4, potential values were plotted also with respect to the ideal SHE reference electrode (see upper X-axis). 
Table 1 reports relevant voltammetric parameters obtained from the above CVs as well as from those recorded changing the scan rate from 10 to $80 \mathrm{mV} \mathrm{s}$.

Table 1. Voltammetric parameters measured from the cyclic voltammograms recorded using the experimental conditions indicated in Figure 4.

\begin{tabular}{|c|c|c|c|c|c|c|c|c|}
\hline $\begin{array}{c}{\left[\mathrm{CuSO}_{4}\right]} \\
(\mathrm{M})\end{array}$ & $\begin{array}{r}\text { Scan } \\
\text { Rate } \\
(\mathrm{mV} / \mathrm{s})\end{array}$ & $\begin{array}{r}\mathrm{E}_{\mathrm{pc}} \mathrm{vs} . \\
\mathrm{Cu} \\
(\mathrm{V})\end{array}$ & $\begin{array}{r}\mathrm{E}_{\mathrm{pc}} \mathrm{vs} . \\
\text { SHE } \\
(\mathrm{V})\end{array}$ & $\begin{array}{r}I_{p c} \\
(m A)\end{array}$ & $\begin{array}{r}\text { E }_{\text {pa }} \text { vs. } \\
\text { Cu } \\
(\mathrm{V})\end{array}$ & $\begin{array}{r}\text { E }_{\text {pa }} \text { vs. } \\
\text { SHE } \\
(V)\end{array}$ & $\begin{array}{r}I_{p a} \\
(m A)\end{array}$ & $\begin{array}{r}A_{\text {pa }} \\
(\mathrm{mC})\end{array}$ \\
\hline \multirow{4}{*}{0.01} & 10 & -0.290 & -0.010 & -0.12 & 0.130 & 0.410 & 1.10 & 8.0 \\
\hline & 20 & -0.350 & -0.070 & -0.20 & 0.135 & 0.415 & 1.48 & 4.0 \\
\hline & 40 & -0.380 & -0.100 & -0.30 & 0.138 & 0.418 & 1.90 & 3.5 \\
\hline & 80 & -0.535 & -0.255 & -0.40 & 0.140 & 0.420 & 2.10 & 1.7 \\
\hline \multirow{4}{*}{0.05} & 10 & -0.280 & -0.020 & -0.68 & 0.132 & 0.432 & 3.50 & 30 \\
\hline & 20 & -0.310 & -0.010 & -0.96 & 0.140 & 0.439 & 4.58 & 18.0 \\
\hline & 40 & -0.340 & -0.040 & -1.50 & 0.156 & 0.456 & 5.80 & 12.0 \\
\hline & 80 & -0.370 & -0.070 & -1.90 & 0.167 & 0.467 & 6.90 & 8.8 \\
\hline \multirow{4}{*}{0.30} & 10 & -0.215 & 0.105 & -4.7 & 0.285 & 0.605 & 14.5 & 220 \\
\hline & 20 & -0.250 & 0.070 & -6.3 & 0.305 & 0.625 & 15.7 & 130 \\
\hline & 40 & -0.300 & 0.020 & -8.5 & 0.320 & 0.640 & 17.9 & 76 \\
\hline & 80 & -0.400 & -0.080 & -11.8 & 0.360 & 0.680 & 19.5 & 50 \\
\hline
\end{tabular}

From these data, the plots shown in Figure 5 were obtained. Figure 5 a shows that the cathodic peak current scales linearly with the $\mathrm{Cu}^{2+}$ concentration. The linear dependence of $\mathrm{I}_{\mathrm{pc}}$ on the square root of the scan rate (see Figure $5 \mathrm{~b}$ ) indicates that, in the electrolyte here used, the reduction of $\mathrm{Cu}^{2+}$ is diffusion controlled [53], with no relevant effects of possible migration effects even at the highest $\mathrm{Cu}^{2+}$ concentration studied here, that is $0.30 \mathrm{M}$.

The anodic peak current showed a more complex dependence both on $\mathrm{Cu}^{2+}$ concentration and scan rate; instead, as expected for a stripping peak, the charge, measured by integrating the anodic peak, scales linearly with the $\mathrm{Cu}^{2+}$ concentration.

Data reported in Table 1 indicate that the cathodic peak potential shifts anodically with increasing the $\mathrm{Cu}^{2+}$ concentration, as expected for a reduction process related to the formation of a metal phase [54-56]:

From an electrodeposition viewpoint, this evidence indicates that it is more convenient to operate at relatively high $\mathrm{Cu}^{2+}$ solution concentrations (i.e., $0.30 \mathrm{M}$ ), where the reduction starts to occur at less-cathodic potential values.

\subsection{Optimization of CuUWs Deposition in PC Membranes}

On the basis of the CV evidence, we examined the deposition of $\mathrm{CuUWs}$ on $\mathrm{Cu}$ and GC working electrodes coated with PC or AAO nanoporous membranes.

\subsubsection{Template Deposition of CuUWs in Polycarbonate Membranes}

On the basis of the $\mathrm{CV}$ results, the deposition was performed under potentiostatic control at $-0.4 \mathrm{~V}$ vs. $\mathrm{Cu}$ (pseudo ref), using $0.3 \mathrm{M} \mathrm{CuSO}_{4}, 2 \mathrm{M} \mathrm{NaSO}_{4}, 10^{-2} \mathrm{M} \mathrm{H}_{2} \mathrm{SO}_{4}$ electrolyte, using a GC or Cu working electrode, coated with the PC membrane, as described in Section 2.3. time.

A key point for the successful growth of $\mathrm{CuUW}$ is the choice of an optimal deposition

Figure 6 shows the SEM image of the deposit obtained using a deposition time of 600s. When using such a deposition time, after filling the pores, copper is also deposited on the outer mouth of the pore, forming mushroom-like structures. On the other hand, other preliminary experiments indicated that deposition times of the order of $60 \mathrm{~s}$ or lower are too 
short to provide any satisfactory copper deposition inside the pores. Finally, it was found that the best time necessary to deposit continuous CuUWs in track-etched polycarbonate is in the $120-240$ s range.

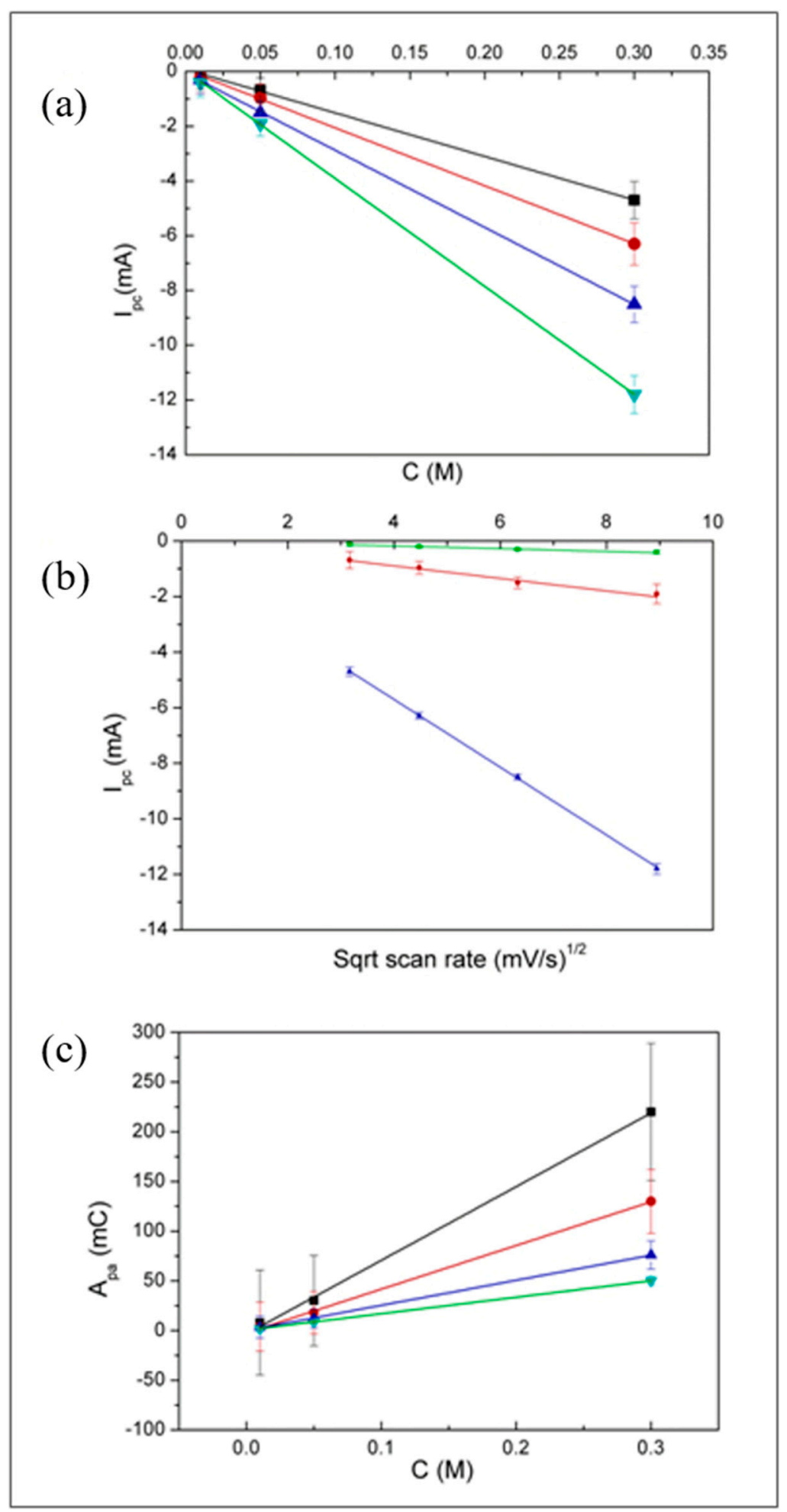

Figure 5. Plots obtained from data in Table 1, showing the dependence of: (a) cathodic peak current vs. $\mathrm{CuSO}_{4}$ concentration, at scan rate: 10 (black); 20 (red); 40 (blue); $80 \mathrm{mV} / \mathrm{s}$ (green); (b) cathodic peak current vs. square root of the scan rate, at $\left[\mathrm{Cu}^{2+}\right]$ : 0.01 (green); 0.05 (red); $0.3 \mathrm{M}$ (blue); (c) electric charge measured by integration of the anodic peak vs. $\mathrm{CuSO}_{4}$ concentration at scan rate: 10 (black); 20 (red); 40 (blue); $80 \mathrm{mV} / \mathrm{s}$ (green). 


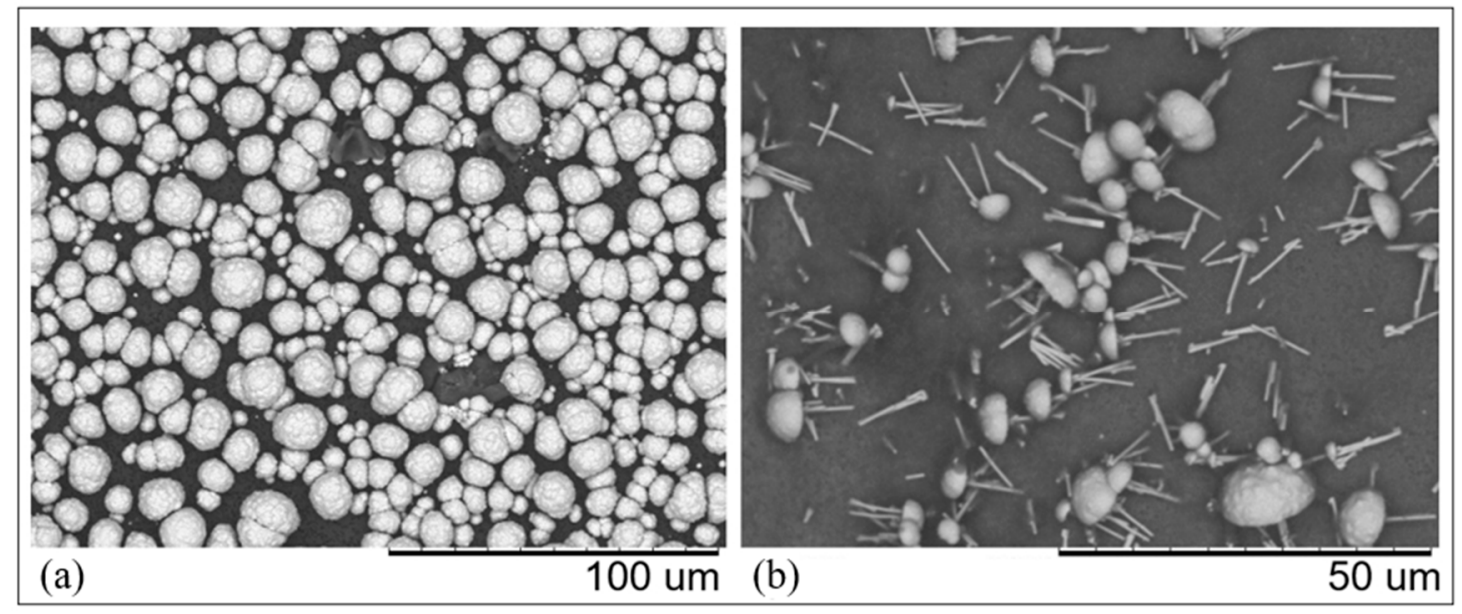

Figure 6. SEM images of the copper deposit obtained using track-etched PC templates onto a GC: (a) surface before etching; (b) mushroom-like nanostructures after etching in $\mathrm{CH}_{2} \mathrm{Cl}_{2}$ for $1 \mathrm{~min}$. Deposition at $-0.400 \mathrm{~V}$ vs. $\mathrm{Cu}$ (pseudo ref) for $600 \mathrm{~s}$; etching in $\mathrm{CH}_{2} \mathrm{Cl}_{2}$ for $1 \mathrm{~min}$.

Figure 7a shows the SEM image of the copper wires obtained by applying $-0.4 \mathrm{~V}$ vs. $\mathrm{Cu}$ (pseudo ref) for $140 \mathrm{~s}$ to a GC working electrode coated by the PC template, and following etching of the template with $\mathrm{CH}_{2} \mathrm{Cl}_{2}$. The main EDS signals shown in Figure 7c confirmed the successful deposition of copper. Signals from other elements were also detected, in particular carbon, oxygen, sulphur, and fluorine, that could be attributed to residual traces of polycarbonate and Nafion.

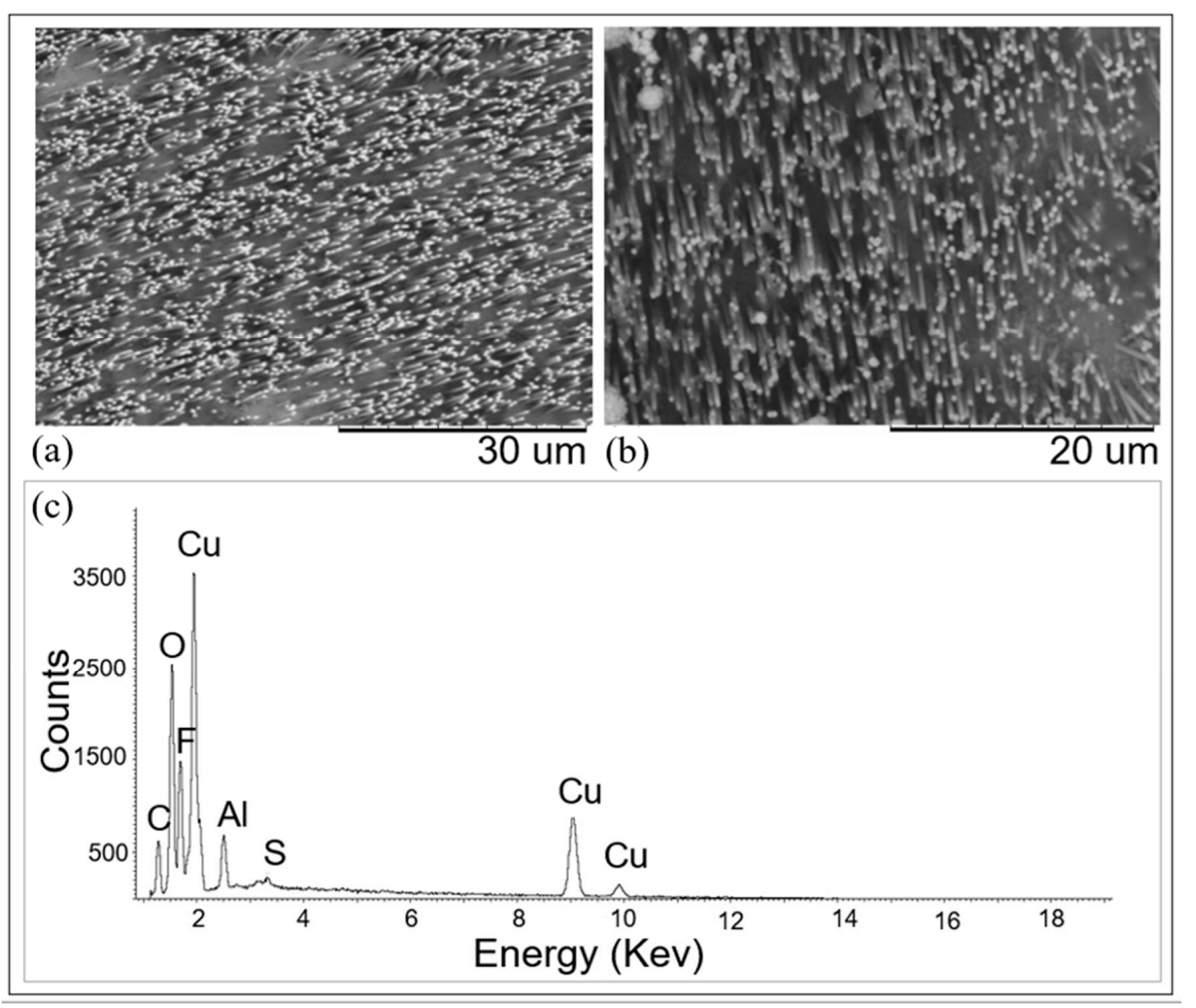

Figure 7. SEM images of CuUWs obtained using track-etched PC templates onto: (a) GC working electrode; (b) Cu working electrode. Deposition at $-0.400 \mathrm{~V}$ vs. $\mathrm{Cu}$ (pseudo ref) for $140 \mathrm{~s}$ (a) and $180 \mathrm{~s}$ (b); etching in $\mathrm{CH}_{2} \mathrm{Cl}_{2}$ for $1 \mathrm{~min}$. (c) EDS spectrum recorded on the CuUWs obtained after template deposition (a). 
Comparable results were obtained at the $\mathrm{Cu}$ working electrode; however, using $180 \mathrm{~s}$ as the deposition time, always at $-0.4 \mathrm{~V}$ vs. $\mathrm{Cu}$ (pseudo ref).

As shown by data in Figure 7 and Figure S1 (in Supplementary Material), the length of the obtained wires was $10.0-10.7 \mu \mathrm{m}$, while their thickness was $350-410 \mathrm{~nm}$, providing an aspect ratio between 24 and 30 .

\subsubsection{Template Deposition of CuUWs in AAO Membranes}

For the case of alumina membranes, no positive results were achieved when using the GC working electrode. This seems related to poor contact (or adhesion) between GC and $\mathrm{AAO}$; the former is indeed hydrophobic and the latter hydrophilic. On the other hand, good results were obtained with the $\mathrm{Cu}$ working electrode, thanks to a good match between these two hydrophilic materials.

Similarly to what is described above for PC, preliminary tests allowed to determine the best conditions to deposit copper ultramicrowires in AAO templates on a $\mathrm{Cu}$ working electrode, which resulted in $300 \mathrm{~s}$ at $-0.250 \mathrm{~V}$ vs. $\mathrm{Cu}$ (pseudo ref).

A longer deposition time was used for the AAO membranes because of their higher thickness. After the deposition, the membranes were etched in $2 \mathrm{M} \mathrm{NaOH}$ for $5 \mathrm{~min}$. The SEM images reported in Figure 8 confirmed the successful growth of CuUWs, which show a length around $30 \mu \mathrm{m}$ and an average thickness of about $250 \mathrm{~nm}$ (see also Figure S2 in Supplementary Material), which means an aspect ratio of around 120.

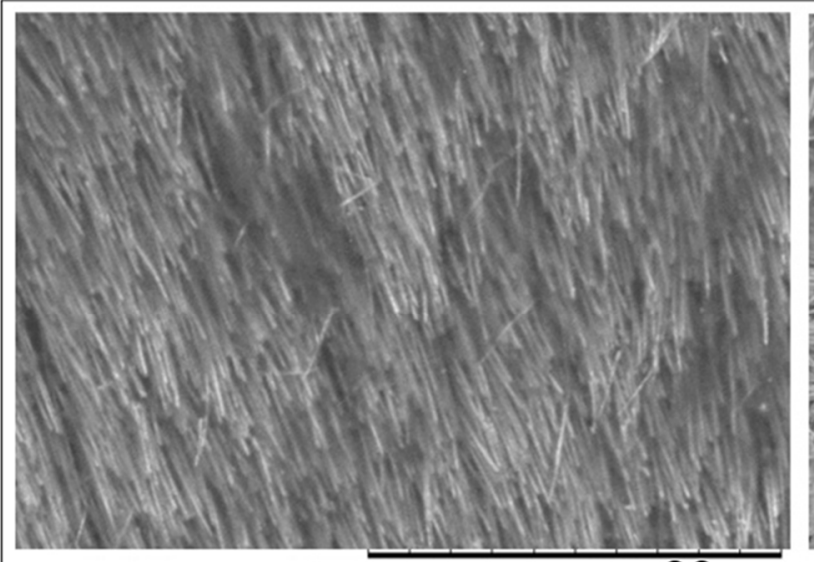

(a)

30 um

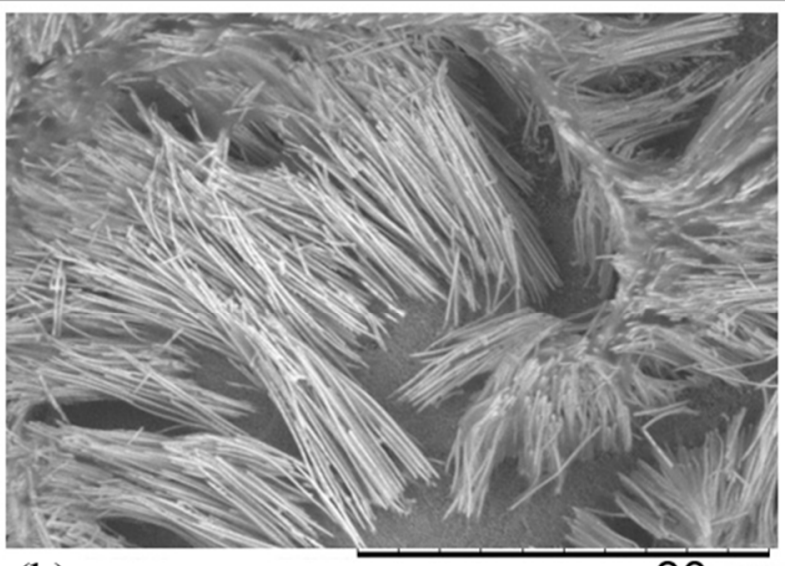

(b)

30 um

Figure 8. SEM images of: (a) self-standing, (b) collapsed CuUWs prepared by using a AAO template onto a Cu working electrode. Deposition at $-0.250 \mathrm{~V}$ vs. $\mathrm{Cu}$ (pseudo ref) for $300 \mathrm{~s}$; etching in $2 \mathrm{M} \mathrm{NaOH}$ for 5 min.

However, as shown by Figure $8 \mathrm{~b}$, the total etching of the template can cause the collapse of the wires, probably because of their excessive length and mechanical weakness of their basis. A similar effect was reported by Du et al. [43] for the case of silver nanowires in AAO, which collapsed after the total etching of the template, while they stayed stable when only partial etching of the membrane was operated.

In summary, the above results indicate that the growth of CuUWs within polycarbonate membranes occurs successfully on both glassy carbon and copper working electrodes, obtaining self-standing CuUW wires after the etching of the template.

On the other hand, the growth of CuUWs on AAO was successful only on copper substrates; in this case, very high aspect ratio wires can be produced, however the obtained structures are much less robust, tending to collapse after the total etching of the membrane. 


\subsection{SERS Detection of Benzenethiol on CuUWs}

In order to test the Raman enhancement effect produced by these copper-based SERS substrates, benzenethiol (BT) [50-59] was chosen as reference Raman probe. A copper plate, named hereafter macro-copper, was employed as control.

Preliminary SERS tests indicated that scarcely reproducible spectra were obtained with the arrays of copper wires prepared in AAO templates. This has been attributed to the above described collapsibility of these wires, similarly to what was previously observed by Du et al. [43] for the case of silver nanowires prepared in AAO, which, once collapsed, became SERS inactive [43]. For this reason, the SERS studies reported below refer only to the more robust arrays of CuUWs obtained with a PC template.

Figure 9 shows the spectra recorded when analyzing BT adsorbed on different substrates from a $10^{-3} \mathrm{M}$ solution. On macro-copper (see Figure 9a), no BT signal was detected. Instead, when CuUWs from PC were employed as the substrate, the typical bands of BT were observed (Figure 9b), indicating the effectiviness of CuUW in producing a detectable enhancement of Raman signals. In particular, the collected spectra displayed three main bands, namely at $996 \mathrm{~cm}^{-1}, 1022 \mathrm{~cm}^{-1}$, and $1072 \mathrm{~cm}^{-1}$, with the appearance of a weaker band at $466 \mathrm{~cm}^{-1}$ [57-61]. The detailed attribution of these, as well as the other BT Raman bands, observed in the collected spectra are reported in Table S1, in Supplementary Material. As can be observed, for some features, more than one possible attribution can be found in the literature. Different authors, provided, in fact, different attributions to different vibrational modes and Table S1 shows the most possible updated overview of given interpretations.
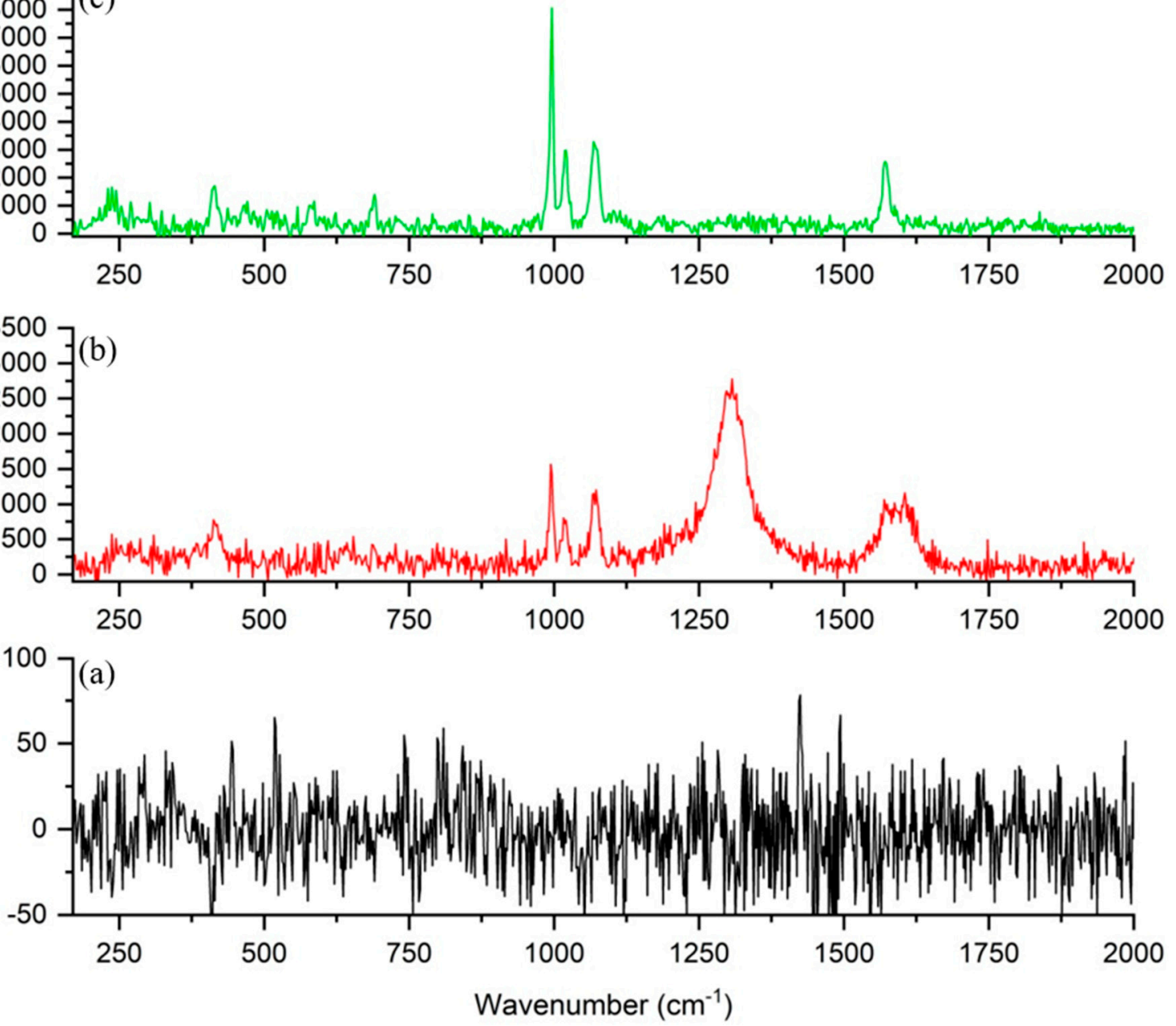

Figure 9. SERS spectra of $10^{-3} \mathrm{M}$ BT recorded on (a) macro-copper, (b) CuUWs, and (c) AgNSs@CuUWs $\left(\lambda_{\mathrm{ex}}=785 \mathrm{~nm}\right.$, $\mathrm{P}=15 \mathrm{~mW}, \mathrm{t}=3 \times 20 \mathrm{~s})$. 
Interestingly, in spectrum (b), the detection of the BT peak expected near $1580 \mathrm{~cm}^{-1}[59,60]$ was indeed hindered by the overlap with two broad bands at 1305 and $1590 \mathrm{~cm}^{-1}$. These two bands resemble the Raman bands, named " $\mathrm{D}$ " $\left(1360 \mathrm{~cm}^{-1}\right)$ and " $\mathrm{G}$ " $\left(1582 \mathrm{~cm}^{-1}\right)$, typical of carbon microstructures, in particular of glassy carbon $[57,62,63]$. Here, their detection was attributed to the GC substrate on which the CuUW structure was grown.

It was recently demonstrated that the combination of arrays of AuNWs with AgNS can bring higher SERS enhancement with respect to arrays of NWs alone, generating an increase in number and efficiency of the SERS-active hot-spots [43]. Therefore, here we tested whether the decoration of CuUWs with AgNSs could provide a similar effect. The spectrum in Figure 9c, recorded with AgNS@CuUW, displayed more intense peaks than spectrum (b). Note that the interference bands by GC became negligible, and the much more intense spectrum of the analyte is now well resolved from the background, thanks to the stronger enhancement characteristics of the bimetallic nano-system.

In particular, the peak of BT at $1570 \mathrm{~cm}^{-1}$ emerged with practically no interference by the GC band at $1550-1600 \mathrm{~cm}^{-1}$. These results confirm the capability of AgNS to produce high SERS enhancements when combined with metal wires of nanoscopic dimension, as a consequence of the generation of highly efficient hot-spots where the stars are in contact the wires, as already demonstrated for the case of gold nanowires decorated with AgNSs [45].

With the aim of quantifying the SERS effect, enhancement factor (EF) values were estimated from the spectra collected on CuUWs and AgNS@CuUW [45,59] by using the area of the peak recorded at $1022 \mathrm{~cm}^{-1}$. The peak area values used in the calculation were the average peak area measured and averaged from three spectra recorded on three different substrate samples. The relative standard deviation (RSD) values of such measurements resulted in 17.5\% and 13.5\% for CuUW and AgNS@CuUW, respectively. For EF evaluation, at first, the approximate surface areas of $\mathrm{CuUW}, \mathrm{AgNSs}$, and relevant hierarchical structures were calculated, estimating geometrical and morphological parameters (namely, geometry, and spatial distribution of the particles) from SEM data [45]. The calculated values are listed in Table 2. Taking into account the laser spot diameter, the surface area of the nanostructures and the benzenethiol molecular area, i.e., $0.22 \mathrm{~nm}^{2} /$ molecule $[59,64]$, the number of molecules excited by the laser beam could be estimated. Enhancements factors (EF) were evaluated with respect to Raman spectra recorded in pure BT liquid, by using Equation (3) [65]:

$$
\mathrm{EF}=\left(I_{\mathrm{SERS}} / N_{\mathrm{SERS}}\right) /\left(I_{\text {Raman }} / N_{\text {Raman }}\right)
$$

where $I_{\text {SERS }}$ (or $I_{\text {Raman }}$ ) refers to the band integral, normalized by the laser power and the exposure time used for the acquisition, while $N_{\text {SERS }}$ (or $N_{\text {Raman }}$ ) refers to the number of BT molecules sampled within the scattering volume. Both $I_{\text {Raman }}$ and $N_{\text {Raman }}$ values were obtained by Raman measurements performed on pure BT solution [45], taken as reference for the EF calculation.

Table 2. Parameters used for the calculation of SERS enhancement factor (EF), for the peak at $1022 \mathrm{~cm}^{-1}$.

\begin{tabular}{|c|c|c|c|c|c|}
\hline Nanomaterial & $\begin{array}{l}\text { Specific Surface } 1 \\
\left(\mathrm{~nm}^{2} / \mathrm{cm}^{2}\right)\end{array}$ & $\begin{array}{c}\text { Surface } \\
\text { Coverage }^{2} \\
\left(\text { Molecules } / \mathrm{cm}^{2}\right)\end{array}$ & $\begin{array}{c}N^{3} \\
\text { (Molecules) }\end{array}$ & $\begin{array}{c}I_{\text {SERS }} 4 \\
(\text { Counts/Watt } \times s)\end{array}$ & $\mathrm{EF}^{5}$ \\
\hline CuUWs & $1.2 \times 10^{15}$ & $5.7 \times 10^{15}$ & $2.5 \times 10^{8}$ & $7.5 \times 10^{4}$ & $0.7 \times 10^{4}$ \\
\hline AgNS@CuNW & $1.80 \times 10^{15}$ & $8.2 \times 10^{15}$ & $3.7 \times 10^{8}$ & $25.0 \times 10^{4}$ & $1.6 \times 10^{4}$ \\
\hline
\end{tabular}

Estimated enhancement factors were $0.7 \times 10^{4}$ and $1.6 \times 10^{4}$ for CuUW and AgNS@CuUW, respectively. These values are similar to the $1.1 \times 10^{4} \mathrm{EF}$ value reported by Yang H-J et al. [47] for the case of 4-mercaptobenzoic acid adsorbed on (self-seeded) copper nanowires with $75 \mathrm{~nm}$ diameter and $18 \mu \mathrm{m}$ length. With respect to BT adsorbed on AuNWs and AgNS@AuNW struc- 
tures [45], the values obtained in this investigation are approximately one order of magnitude lower, indicating a lower efficiency of copper with respect to gold. From a practical viewpoint, the results here reported indicate that SERS effects attainable with CuUWs are still remarkable, supporting the applicability of cheaper than gold CuUWs for SERS measurements; if a greater sensitivity is requested, decoration with AgNS can be used.

\section{Conclusions}

The results achieved in this work provide evidence that the growth of copper ultramicrowires in PC membranes occurs successfully both on copper and glassy carbon substrate electrodes, while for the case of AAO membranes, good results can be obtained only on copper electrodes, probably because of adhesion problems between AAO and GC. The choice of optimized deposition time and potential allow the preparation of ordered arrays of CuUWs with high aspect ratio both from AAO and PC; however, the nanostructures obtained from the PC template are mechanically more robust, probably because residual traces of PC left after the etching help in keeping a solid anchoring of the ultramicrowires on the substrate.

The developed CuUW substrates display good SERS enhancement properties for adsorbed benzenthiol, which are further improved after decoration with AgNSs. The sensitivity with CuUW and AgNS@CuUW substrates is slightly lower than that with AuNWs or AgNS@AuNW. Further focused studies are required to understand if such differences are related to the nature or morphology of these CuUW or are rather due to differences in the interaction of BT with CuUW vs. AuNWs. Anyhow, the results here presented indicate that CuUW structures can be useful for studying Raman active molecules, in particular for obtaining mechanistic information on catalytic processes where copper is involved, or when efficient but cheap SERS substrates are desired.

Supplementary Materials: The following are available online at https:/ / www.mdpi.com/2079-499 $1 / 11 / 2 / 518 /$ s1. Figure S1. Detail of SEM analysis of copper wires prepared in a PC template on GC working electrode; Figure S2. Detail of SEM analysis of copper wires prepared in an AAO template on $\mathrm{Cu}$ working electrode. Table S1. Analysis of the vibrational spectral features of benzenethiol and related literature references.

Author Contributions: Conceptualization, M.L., M.S.Z., and P.U.; formal analysis, M.L., M.S.Z., and L.d.F., P.U.; investigation, M.L., M.S.Z., L.d.F., and A.M.S.; methodology, M.L., M.S.Z., L.d.F., A.M.S., and P.U.; project administration, G.P. and P.U.; supervision, G.P., A.M.S., and P.U.; validation, M.S.Z., L.d.F., G.P., and P.U.; visualization, M.L., M.S.Z., L.d.F., A.M.S., and P.U.; writing-original draft preparation, M.L., M.S.Z., L.d.F., A.M.S., and P.U.; writing—review and editing, M.L., M.S.Z., L.d.F., A.M.S., G.P., and P.U. All authors have read and agreed to the published version of the manuscript.

Funding: This research received no external funding.

Institutional Review Board Statement: Not applicable for studies not involving humans or animals. Informed Consent Statement: Not applicable for studies not involving humans.

Data Availability Statement: Data is available upon the reasonable request from the corresponding author.

Acknowledgments: The authors thank InRedox (Longmont, CO, USA) for the gift of AAO wafer membranes and Madatec srl (Pessano con Bornago, Italy), BWTec distributor, for technical support. The authors also thank Patrizia Canton (University Ca' Foscari of Venice, DSMN) for TEM analysis.

Conflicts of Interest: The authors declare no conflict of interest.

\section{References}

1. Karimian, N.; Ugo, P. Recent advances in sensing and biosensing with arrays of nanoelectrodes. Curr. Opin. Electrochem. 2019, 16, 106-116. [CrossRef]

2. LaFratta, C.N.; Walt, D.R. Very High Density Sensing Arrays. Chem. Rev. 2008, 108, 614-637. [CrossRef] [PubMed]

3. Ziegler, J.M.; Andoni, I.; Choi, E.J.; Fang, L.; Flores-Zuleta, H.; Humphrey, N.J.; Kim, D.-H.; Shin, J.; Youn, H.; Penner, R.M. Sensors Based Upon Nanowires, Nanotubes, and Nanoribbons: 2016-2020. Anal. Chem. 2021, 93, 124-166. [CrossRef] 
4. Habtamu, H.B.; Ugo, P. Miniaturized Enzymatic Biosensor via Biofunctionalization of the Insulator of Nanoelectrode Ensembles. Electroanalysis 2015, 27, 2187-2193. [CrossRef]

5. Gaetani, C.; Gheno, G.; Borroni, M.; De Wael, K.; Moretto, L.M.; Ugo, P. Nanoelectrode ensemble immunosensing for the electrochemical identification of ovalbumin in works of art. Electrochim. Acta 2019, 312, 72-79. [CrossRef]

6. Dahlin, A.B. Size Matters: Problems and Advantages Associated with Highly Miniaturized Sensors. Sensors 2012, 12, 3018-3036. [CrossRef] [PubMed]

7. Murphy, C.J.; Jana, N.R. Controlling the Aspect Ratio of Inoragnic Nanorods and Nanowires. Adv. Mater. 2002, 14, 80-83. [CrossRef]

8. Zalaffi, M.S.; Karimian, N.; Ugo, P. Review-Electrochemical and SERS Sensors for Cultural Heritage Diagnostics and Conservation: Recent Advances and Prospects. J. Electrochem. Soc. 2020, 167, 037548. [CrossRef]

9. Dahlin, A.B.; Dielacher, B.; Rajendran, P.; Sugihara, K.; Sannomiya, T.; Zenobi-Wong, M.; Voros, J. Electrochemical plasmonic sensors. Anal. Bioanal. Chem. 2012, 402, 1773-1784. [CrossRef] [PubMed]

10. Park, S.-G.; Kang, M.; Kim, S.; Jung, H.S.; Kim, D.-H. 3D-assembled Ag nanowires for use in plasmon-enhanced spectroscopic sensors. Appl. Spectrosc. Rev. 2019, 54, 325-347. [CrossRef]

11. Possin, G.E. A Method for Forming Very Small Diameter Wires. Rev. Sci. Instrum. 1970, 41, 772. [CrossRef]

12. Penner, R.M.; Martin, C.R. Preparation and electrochemical characterization of ultramicroelectrode endembles. Anal. Chem. 1987, 59, 2625-2630. [CrossRef]

13. Martin, C.R. Membrane-based synthesis of nanomaterials. Chem. Mater. 1996, 8, 1739-1746. [CrossRef]

14. Ugo, P.; Moretto, L.M. Template deposition of metals. In Handbook of Electrochemistry; Zoski, C.G., Ed.; Elsevier: Amsterdam, The Netherlands, 2007; pp. 678-709. ISBN 978-0-444-51958-0. [CrossRef]

15. Inguanta, R.; Piazza, S.; Sunseri, C. Novel procedure for the template synthesis of metal nanostructures. Electrochem. Commun. 2008, 10, 506-509. [CrossRef]

16. Menon, V.P.; Martin, C.R. Fabrication and Evaluation of Nanoelectrode Ensembles. Anal. Chem. 1995, 67, 1920-1928. [CrossRef]

17. Diggle, W.J.; Downie, C.T.; Goulding, W.C. Anodic oxide films on aluminum. Chem. Rev. 2002, 69, 365-405. [CrossRef]

18. Sarkar, J.; Khan, G.G.; Basumallick, A. Nanowires: Properties, applications and synthesis via porous aluminium oxide template. Bull. Mater. Sci. 2007, 30, 271-290. [CrossRef]

19. Sousa, C.T.; Leitao, D.C.; Proenca, M.P.; Ventura, J.; Pereira, A.M.; Araujo, J.P. Nanoporous alumina as templates for multifunctional applications. Appl. Phys. Rev. 2014, 1, 031102. [CrossRef]

20. Giallongo, G.; Durante, C.; Pilot, R.; Garoli, D.; Bozio, R.; Romanato, F.; Gennaro, A.; Rizzi, G.A.; Granozzi, G. Growth and optical properties of silver nanostructures obtained on connected anodic aluminum oxide templates. Nanotechnology 2012, $23,325604$. [CrossRef] [PubMed]

21. Whitney, T.M.; Jiang, J.S.; Searson, P.C.; Chien, C.L. Fabrication and magnetic-properties of arrays of metallic nanowires. Science 1993, 261, 1316-1319. [CrossRef] [PubMed]

22. Schonenberger, C.; Van der Zande, B.M.I.; Fokkink, L.G.J.; Henny, M.; Schmid, C.; Kruger, M.; Bachtold, A.; Huber, R.; Birk, H.; Staufer, U. Template synthesis of nanowires in porous polycarbonate membranes: Electrochemistry and morphology. J. Phys. Chem. B 1997, 101, 5497-5505. [CrossRef]

23. Blanco, S.; Vargas, R.; Mostany, J.; Borrás, C.; Scharifker, B.R. Modeling the Growth of Nanowire Arrays in Porous Membrane Templates. J. Electrochem. Soc. 2014, 161, E3341-E3347. [CrossRef]

24. Davydov, A.D.; Volgin, V.M. Template electrodeposition of metals. Review. Russ. J. Electrochem. 2016, 52, 806-831. [CrossRef]

25. Yu, S.; Li, N.; Wharton, J.; Martin, C.R. Nano wheat fields prepared by plasma-etching gold nanowire-containing membranes. Nano Lett. 2003, 3, 815-818. [CrossRef]

26. Gasparac, R.; Taft, B.J.; Lapierre-Devlin, M.A.; Lazareck, A.D.; Xu, J.M.; Kelley, S.O. Ultrasensitive electrocatalytic DNA detection at two- and three-dimensional nanoelectrodes. J. Am. Chem. Soc. 2004, 126, 12270-12271. [CrossRef] [PubMed]

27. De Leo, M.; Kuhn, A.; Ugo, P. 3D-ensembles of gold nanowires: Preparation, characterization and electroanalytical peculiarities. Electroanalysis 2007, 19, 227-236. [CrossRef]

28. Cao, L.; Yan, P.; Sun, K.; Wirk, D.W. Tailor-made gold brush nanoelectrode ensembles modified with L-cysteine for the detection of daunorubicine. Electrochim. Acta 2008, 53, 8144-8148. [CrossRef]

29. Beluomini, M.A.; Karimian, N.; Stradiotto, N.R.; Ugo, P. Tailor-made 3D-nanoelectrode ensembles modified with molecularly imprinted poly(o-phenylenediamine) for the sensitive detection of L-arabitol. Sens. Actuators B-Chem. 2019, 284, 250-257. [CrossRef]

30. Gao, T.; Meng, G.W.; Wang, Y.W.; Sun, S.H.; Zhang, L. Electrochemical synthesis of copper nanowires. J. Phys. Condens. Matter 2002, 14, 355-363. [CrossRef]

31. Ganapathi, A.; Swaminathan, P.; Neelakantan, L. Anodic Aluminum Oxide Template Assisted Synthesis of Copper Nanowires using a Galvanic Displacement Process for Electrochemical Denitrification. ACS Appl. Nano Mater. 2019, 2, 5981-5988. [CrossRef]

32. Stortini, A.M.; Moretto, L.M.; Mardegan, A.; Ongaro, M.; Ugo, P. Arrays of copper nanowire electrodes: Preparation, characterization and application as nitrate sensor. Sens. Actuators B Chem. 2015, 207, 186-192. [CrossRef]

33. Stortini, A.M.; Fabris, S.; Saorin, G.; Falzacappa, E.V.; Moretto, L.M.; Ugo, P. Plasma Activation of Copper Nanowires Arrays for Electrocatalytic Sensing of Nitrate in Food and Water. Nanomaterials 2019, 9, 150. [CrossRef] [PubMed]

34. Patella, B.; Russo, R.R.; O'Riordan, A.; Aiello, G.; Sunseri, C.; Inguanta, R. Copper nanowire array as highly selective electrochemical sensor of nitrate ions in water. Talanta 2021, 221, 121643. [CrossRef] [PubMed] 
35. Fleischmann, M.; Hendra, P.J.; McQuillan, A.J. Raman spectra of pyridine adsorbed at a silver electrode. Chem. Phys. Lett. 1974, 26, 163-166. [CrossRef]

36. Moskovits, M. Surface-enhanced Raman spectroscopy: A brief retrospective. J. Raman Spectrosc. 2005, 36, 485-496. [CrossRef]

37. Bantz, K.C.; Meyer, A.F.; Wittenberg, N.J.; Im, H.; Kurtulus, O.; Lee, S.H.; Lindquist, N.C.; Oh, S.-H.; Haynes, C.L. Recent progress in SERS biosensing. Phys. Chem. Chem. Phys. 2011, 13, 11551-11567. [CrossRef] [PubMed]

38. Pilot, R.; Signorini, R.; Durante, C.; Orian, L.; Bhamidipati, M.; Fabris, L. A Review on Surface-Enhanced Raman Scattering. Biosensors 2019, 9, 57. [CrossRef]

39. Chourpa, I.; Lei, F.H.; Dubois, P.; Manfait, M.; Sockalingum, G.D. Intracellular applications of analytical SERS spectroscopy and multispectral imaging. Chem. Soc. Rev. 2008, 37, 993-1000. [CrossRef] [PubMed]

40. Lussier, F.; Brule, T.; Vishwakarma, M.; Das, T.; Spatz, J.P.; Masson, J.-F. Dynamic-SERS Optophysiology: A Nanosensor for Monitoring Cell Secretion Events. Nano Lett. 2016, 16, 3866-3871. [CrossRef]

41. Lee, S.J.; Baik, J.M.; Moskovits, M. Polarization-Dependent Surface-Enhanced Raman Scattering from a Silver-NanoparticleDecorated Single Silver Nanowire. Nano Lett. 2008, 8, 3244-3247. [CrossRef]

42. Liu, S.; Chen, N.; Li, L.; Pang, F.; Chen, Z.; Wang, T. Fabrication of Ag/Au core-shell nanowire as a SERS substrate. Opt. Mater. 2013, 35, 690-692. [CrossRef]

43. Du, Y.; Shi, L.; He, T.; Sun, X.; Mo, Y. SERS enhancement dependence on the diameter and aspect ratio of silver-nanowire array fabricated by anodic aluminium oxide template. Appl. Surf. Sci. 2008, 255, 1901-1905. [CrossRef]

44. Sun, B.; Jiang, X.; Dai, S.; Du, Z. Single-crystal silver nanowires: Preparation and Surface-enhanced Raman Scattering (SERS) property. Mater. Lett. 2009, 63, 2570-2573. [CrossRef]

45. Zalaffi, M.S.; Litti, L.; Canton, P.; Meneghetti, M.; Moretto, L.M.; Ugo, P. Preparation and characterization of Ag-nanostars@Aunanowires hierarchical nanostructures for highly sensitive surface enhanced Raman spectroscopy. Nano Express 2020, 1, 020006. [CrossRef]

46. Halouzka, V.; Halouzkova, B.; Jirovsky, D.; Hemzal, D.; Ondra, P.; Siranidi, E.; Kontos, A.G.; Falaras, P.; Hrbac, J. Copper nanowire coated carbon fibers as efficient substrates for detecting designer drugs using SERS. Talanta 2017, 165, 384-390. [CrossRef] [PubMed]

47. Yang, H.-J.; He, S.-Y.; Tuan, H.-Y. Self-Seeded Growth of Five-Fold Twinned Copper Nanowires: Mechanistic Study, Characterization and SERS Applications. Langmuir 2014, 30, 602-610. [CrossRef]

48. Xu, D.; Dong, Z.; Sun, J.-L. Fabrication of copper nanowires by a solid-state ionics method and their surface enhanced Raman scattering effect. Mater. Lett. 2013, 92, 143-146. [CrossRef]

49. Ugo, P.; Moretto, L.M.; Mazzocchin, G.A. Ion-exchange voltammetry of copper ions in chloride media at glassy carbon electrodes modified with polycationic ionomers. Anal. Chim. Acta 1993, 273, 229-236. [CrossRef]

50. Garcia-Leis, A.; Garcia-Ramos, J.V.; Sanchez-Cortes, S. Silver Nanostars with High SERS Performance. J. Phys. Chem. C 2013, 117, 12397. [CrossRef]

51. Zalaffi, M.S.; Agostinelli, I.; Karimian, N.; Ugo, P. Ag-Nanostars for the Sensitive SERS Detection of Dyes in Artistic CrossSections-Madonna della Misericordia of the National Gallery of Parma: A Case Study. Heritage 2020, 3, 1344-1359. [CrossRef]

52. Milchev, A.; Zapryanova, T. Nucleation and growth of copper under combined charge transfer and diffusion limitations: Part I. Electrochim. Acta 2006, 51, 2926-2933. [CrossRef]

53. Milchev, A.; Zapryanova, T. Nucleation and growth of copper under combined charge transfer and diffusion limitations - Part II. Electrochim. Acta 2006, 51, 4916-4921. [CrossRef]

54. Bard, A.J.; Faulkner, L. Electrochemical Methods Fundamentalsand Applications, 2nd ed.; Wiley: New York, NY, USA, 2001; ISBN 0-471-04372-9. [CrossRef]

55. Vydra, F.; Stulik, K.; Julakova, E. Electrochemical stripping analysis. In Ellis Horwood Series in Analytical Chemistry; Red, H.P., Ed.; Prentice Hall: New York, NY, USA, 1976; ISBN 10: 085312017X/ISBN 13: 9780853120179.

56. Moretto, L.M.; Mazzocchin, G.A.; Ugo, P. Electroanalytical study on the ion-exchange voltammetric behaviour of Hg(II) at Tosflex(R)-coated glassy carbon electrodes. J. Electroanal. Chem. 1997, 427, 113-121. [CrossRef]

57. Joo, T.H.; Kim, M.S.; Kim, K. Surface-enhanced Raman-scattering of benzenethiol in silver sol. J. Raman Spectrosc. 1987, 18, 57-60. [CrossRef]

58. McFarland, A.D.; Young, M.A.; Dieringer, J.A.; Van Duyne, R.P. Wavelength-scanned surface-enhanced Raman excitation spectroscopy. J. Phys. Chem. B 2005, 109, 11279-11285. [CrossRef] [PubMed]

59. Zamuner, M.; Talaga, D.; Deiss, F.; Guieu, V.; Kuhn, A.; Ugo, P.; Sojic, N. Fabrication of a Macroporous Microwell Array for Surface-Enhanced Raman Scattering. Adv. Funct. Mater. 2009, 19, 3129-3135. [CrossRef]

60. Aggarwal, R.L.; Farrar, L.W.; Diebold, E.D.; Polla, D.L. Measurement of the absolute Raman scattering cross section of the $1584 \mathrm{~cm}^{-1}$ band of benzenethiol and the surface-enhanced Raman scattering cross section enhancement factor for femtosecond laser-nanostructured substrates. J. Raman Spectrosc. 2009, 40, 1331-1333. [CrossRef]

61. Fontana, J.; Livenerec, J.; Bezares, F.J.; Caldwell, J.D.; Rendell, R.; Ratna, B.R. Large surface-enhanced Raman scattering from self-assembled gold nanosphere monolayers. Appl. Phys. Lett. 2013, 102. [CrossRef]

62. McCreery, R.I. Advanced Carbon Electrode Materials for Molecular Electrochemistry. Chem. Rev. 2008, 108, 2646-2687. [CrossRef]

63. Mardegan, A.; Kamath, R.; Sharma, S.; Scopece, P.; Ugo, P.; Madou, M. Optimization of Carbon Electrodes Derived from Epoxy-based Photoresist. J. Electrochem. Soc. 2013, 160, B132-B137. [CrossRef] 
64. Guieu, V.; Lagugne-Labarthet, F.; Servant, L.; Talaga, D.; Sojic, N. Ultrasharp Optical Fiber Nanoprobe Array for Raman Local Enhancement Imaging. Small 2008, 4, 96-99. [CrossRef] [PubMed]

65. Le Ru, E.C.; Blackie, E.; Meyer, M.; Etchegoin, P.G. Surface Enhanced Raman Scattering Enhancement Factors: A Comprehensive Study. J. Phys. Chem. C 2007, 111, 13794-13803. [CrossRef] 